\title{
Growth and Energy Expenditures of Eurasian Perch Perca fluviatilis (Linnaeus) in Different Temperatures and of Different Body Sizes
}

\author{
Ása Strand*, Carin Magnhagen and Anders Alanärä
}

Department of Wildlife, Fish and Environmental Studies, Swedish University of Agricultural Sciences, S-901 83 Umeå, Sweden

\begin{abstract}
To calculate the theoretical daily energy requirement of fish, information about the daily growth increment and the amount of digestible energy needed (DEN) to obtain one unit of biomass gain is required. The thermal unit growth coefficient (TGC) can be used for estimation of the daily growth increment. TGC is thought to be less affected by body size of the fish and temperature than the specific growth rate (SGR). However, there are some indications that the TGC may not be as stable as previous studies have shown. Furthermore, according to the theoretical background, DEN should increase as fish body size increases and with temperature. However, some data indicate that the DEN for percid fish may be unaffected by both these factors. The main objectives of this study was to estimate the effects of temperature and fish body weight on growth (TGC and SGR) and digestible energy need (DEN) of the Eurasian perch Perca fluviatilis (Linnaeus). In two separate laboratory experiments, feed intake, growth and energy expenditures were measured at either different temperatures $\left(8.5-27.1^{\circ} \mathrm{C}\right)$ or for fish of different body sizes $(20-110 \mathrm{~g})$. TGC and SGR proved to be affected by temperature and body size of the fish, while DEN was only affected by body size. The advantages with TGC for growth model construction thus seem to be less apparent than earlier believed. Thus, for evaluation of the theoretical daily energy requirement of fish, a growth model including both temperature and body size of fish, and an energy expenditure model including body size of fish is required.
\end{abstract}

Keywords: Perca Fluviatilis; Temperature; Body size; Growth rate; TGC; Energy expenditures; DEN

\section{Introduction}

To calculate feed requirements of farm animals, approaches based on energetic principles are frequently used. For livestock, the extent of nutritional knowledge is much more developed compared to that of fish, and there is a long tradition to utilize this knowledge for calculation of the daily feed allowances of the animals [1,2]. The energy requirements of fish has traditionally been estimated by constructing complete energy budgets, balancing energy intake against energy expenditures such as faecal production, nitrogen excretion, metabolism and growth [3-6]. Despite improvements in methodology, this approach is often associated with several potential sources of error $[4,5,7,8]$ and many of the developed energy budgets prove to deliver inaccurate results when tested [9-11].

Due to the problems with the classical bioenergetics approach, a more general method to calculate the theoretical daily energy requirement $\left(\mathrm{kJ}^{\circ} \mathrm{day}^{-1}\right)$ of fish was developed by Alanärä et al. [12]. The proposed model was based on two major components; one that estimates the daily growth increment $(\mathrm{g})$ of the fish and one that calculates the amount of digestible energy needed $(\mathrm{kJ})$ to obtain one unit of biomass gain $(\mathrm{g})$ of the fish.

There are several ways to calculate the daily growth increment of fish. The most commonly used estimate of fish growth is the specific growth rate (SGR, [13]). However, as SGR is affected by both temperature [14-17] and body size of the fish [5,18-20] data collection for model construction is very time consuming and labour demanding. To reduce the problem with the effect of body size when expressing growth rate, Iwama \& Tautz [21] developed another growth index, the daily growth coefficient (DGC). Instead of using the logarithm of the fish weight for calculating growth rate as SGR does, DGC uses a power function $\left(\mathrm{W}^{1 / 3}\right)$. This mathematical adjustment of the growth coefficient provides a better fit to the actual growth pattern of the fish $[20,21]$, and in accordance, DGC have been found to be more stable over a range of body weights [22].

As a final developmental stage, temperature was added to the DGC equation, resulting in the formation of the thermal unit growth coefficient (TGC, [21]). Due to the mathematical structure of the TGC coefficient and with the inclusion of temperature in the calculation of growth rate, TGC is thought to be less affected by body size of the fish [22-24] and temperature [24-26] than SGR. In addition, the TGC coefficient has been shown to predict growth over time quite accurately $[21,27]$. However, there are some indications that the TGC may not be as stable as previous studies have shown $[28,29]$. Whether the TGC of Eurasian perch (from here on referred to as perch) is affected by temperature and fish body size has not earlier been thoroughly studied.

Data on digestible energy need (DEN) of the fish can be obtained by measuring the digestible energy intake of fish divided by the obtained growth. The advantage with the DEN model is that since the values for the different energy expenditures need not be quantified, estimates of the energy requirements can be made when the fish are being raised under normal culture conditions. As standard metabolic rate of fish increases with increasing temperature $[5,30,31]$ so does the energy expenditures of the fish, and hence the DEN values. Moreover, as fish increases in size, a shift in fish body composition occurs, with increased deposition of fat in larger fish [4,5]. The energy value of fat is much higher compared to that of protein [3] and deposition of fat also leads to less deposition of water in the body compared to when proteins are

*Corresponding author: Department of Wildlife, Fish and Environmenta Studies, Swedish University of Agricultural Sciences, S-901 83 Umeå, Sweden, Tel:+46907868571, Fax:+469078608162; E-mail: asa.strand@slu.se

Received March 08, 2011; Accepted June 20, 2011; Published July 05, 2011

Citation: Strand $\AA$, Magnhagen C, Alanärä A (2011) Growth and Energy Expenditures of Eurasian Perch Perca fluviatilis (Linnaeus) in Different Temperatures and of Different Body Sizes. J Aquac Res Development 2:114. doi:10.4172/2155-9546.1000114

Copyright: ( 2011 Strand $\AA$, et al. This is an open-access article distributed under the terms of the Creative Commons Attribution License, which permits unrestricted use, distribution, and reproduction in any medium, provided the original author and source are credited. 
Citation: Strand Å, Magnhagen C, Alanärä A (2011) Growth and Energy Expenditures of Eurasian Perch Perca fluviatilis (Linnaeus) in Different Temperatures and of Different Body Sizes. J Aquac Res Development 2:114. doi:10.4172/2155-9546.1000114

Page 2 of 8

deposited [5]. As a consequence, DEN should increase as fish body size increases. However, data presented by Bailey and Alanärä [32] indicate that the DEN value of percid fish may be unaffected by both these factors. The temperature and body size dependence of DEN for perch thus needs to be evaluated further

The main purposes of this study were to estimate the effects of temperature and fish body weight on growth (TGC and SGR) and digestible energy need (DEN) of perch. We predicted that SGR and DEN but not TGC would be affected by temperature and body size of the fish.

\section{Material and Methods}

\section{Fish and rearing}

In autumn 2004, young-of-the-year perch were bought from a fish hatchery (located in Söderköping: $58^{\circ} 48^{\prime} \mathrm{N}$; $16^{\circ} 34^{\prime} \mathrm{E}$, Sweden) and transported to the university research facility in Umeå, Sweden $\left(63^{\circ} 47^{\prime} \mathrm{N} ; 20^{\circ} 17^{\prime} \mathrm{E}\right)$. The juveniles were hatched from eggs collected from wild spawners, and the fry were habituated to dry feed before they were delivered to the research facility. At the research facility, the juveniles were placed in square, grey, fibreglass indoor tanks $(0.3$ $\left.\mathrm{m}^{3}\right)$. The water used in the facility was tap water, which was aerated and heated to approximately $17^{\circ} \mathrm{C}$ in the tanks. The light regime was 12L:12D, with light switched on at 07.00 and off at 19.00. During ongrowing, the fish were fed with increasingly larger pellet sizes (Dana Feed, Horsens, Denmark, DAN-EX 1051, $1 \mathrm{~mm}$ and $1.8 \mathrm{~mm}$ and DANEX 1344, 2 and $3 \mathrm{~mm}$ ) delivered by automatic point source feeders set to deliver feed in excess.

\section{Experimental setup}

Twelve dark green cylindrical plastic tanks $(100 \mathrm{~L})$ were used in the experimental setup. Inside each tank was a plastic cone connected to a hole in the tank bottom, creating a space (approximately $55 \mathrm{~L}$ ) with tilting walls, thus enabling uneaten pellets to tumble down along the walls to the collection hole in the bottom of the tank. For more details regarding the experiment tanks please refer to Strand et al. [33]. An automatic point source feeder was placed above each tank. The feeders (manufactured by Storvik AS, Norway) were set to deliver formulated feed (DAN-EX 1344, 2 or $3 \mathrm{~mm}, 13 \%$ fat, $44 \%$ protein, $25 \%$ carbohydrates, Dana feed, Horsens, Denmark,) in excess. The daily feed ration was divided into two meals, at 07.00-09.00 and 18.00-19.00. Feed waste and faeces were automatically evacuated from the tanks daily at pre-programmed time intervals. The number of pellets flushed out from each tank was counted daily. The light regime used was $16 \mathrm{~L}$ : $8 \mathrm{D}$, with light (125 lux at surface) switched on at 06.00 and off at 22.00 . Flow rates to the tanks were about four litres per minute. All tanks were separated by black plastic sheets.

The experiment regarding effect of temperature was performed during May to July 2005 when the fish were approximately one year. The optimal temperature for growth of perch is reported to be between $23^{\circ} \mathrm{C}[34,35]$ and $26^{\circ} \mathrm{C}$ [36], and the temperature preference is considered to be 18 to $27^{\circ} \mathrm{C}$ [36], although growth can occur as low as $14^{\circ} \mathrm{C}$ [37] to $11^{\circ} \mathrm{C}$ [34]. For this reason, the temperature range in the experiment was set to between 8 and $27^{\circ} \mathrm{C}$. Five different temperature regimes (average temperatures $\pm \mathrm{SD}$ ) were used in the experiment; 8.5 $\pm 0.8^{\circ} \mathrm{C}$, three tanks; $12.9 \pm 0.4^{\circ} \mathrm{C}$, three tanks; $18.2 \pm 0.4^{\circ} \mathrm{C}$, two tanks; $23.1 \pm 0.5^{\circ} \mathrm{C}$, two tanks; $27.1 \pm 2.2^{\circ} \mathrm{C}$, two tanks. The temperature of each tank was recorded continuously by temperature loggers. For tanks with high temperatures $\left(18-27^{\circ} \mathrm{C}\right)$ the duration of the experiment was three weeks, and the experiment was repeated in three consecutive rounds (experimental round $1 \mathrm{a}, \mathrm{b}$ and $\mathrm{c}$ ). Three weeks has previously been demonstrated to be long enough to allow reliable recordings of growth of perch reared at $23^{\circ} \mathrm{C}$ [38]. However, as growth of the species in low temperatures $\left(<14^{\circ} \mathrm{C}\right)$ is very slow $[34,37]$, a longer period was chosen for low temperatures in this study to provide time enough for measurable growth to occur. In tanks with low temperatures ( 8 and $13^{\circ} \mathrm{C}$ ) the experiment was thus extended to four weeks and was repeated in two consecutive rounds (experimental round $2 \mathrm{a}$ and $\mathrm{b}$ ). Experimental rounds for both high and low temperatures were run in parallel. By having different duration of the experimental rounds for high and low temperatures, respectively, identical numbers of replicates could be obtained for all temperatures while limiting the experiment to approximately two months. This was desirable in order to reduce season related variations in growth $[39,40]$. Groups of eight fish were used and initial average live weight $( \pm$ SD) of the fish was $28.3 \mathrm{~g}( \pm$ 6.9). At the start and end of each experimental round, the feed (DAN-

\begin{tabular}{|c|c|c|c|c|c|c|c|c|}
\hline \multirow[b]{2}{*}{$\begin{array}{l}\text { Experimental } \\
\text { round }\end{array}$} & \multirow[b]{2}{*}{ Dates } & \multirow[b]{2}{*}{$\begin{array}{c}\text { Temperature } \\
\text { category }\end{array}$} & \multirow[b]{2}{*}{$\begin{array}{l}\text { Average tem- } \\
\text { perature }\left({ }^{\circ} \mathrm{C}\right)\end{array}$} & \multirow[b]{2}{*}{ Average $W_{1}(g)^{2}$} & \multirow[b]{2}{*}{ Average $\mathrm{W}_{2}(\mathrm{~g})^{3}$} & \multirow[b]{2}{*}{$\begin{array}{l}\text { Number of } \\
\text { fish.group }{ }^{-1}\end{array}$} & \multicolumn{2}{|c|}{ Number of replicates } \\
\hline & & & & & & & $\begin{array}{l}\text { SGR, TGC, feed } \\
\left.\text { intake ( } \% \text { of BW } \text { BW }^{1}\right)\end{array}$ & DEN \\
\hline \multirow{3}{*}{$1 \mathrm{a}$} & \multirow{3}{*}{ May 12-June 2} & 18 & 18.0 & 33.0 & 37.0 & 8 & 2 & 2 \\
\hline & & 23 & 22.7 & 31.3 & 34.3 & 8 & 2 & 2 \\
\hline & & 27 & 26.9 & 33.6 & 23.3 & 8 & 2 & 0 \\
\hline \multirow{3}{*}{$1 b$} & \multirow{3}{*}{ June 2- June 23} & 18 & 18.4 & 26.6 & 35.3 & 7 & 2 & 2 \\
\hline & & 23 & 23.1 & 24.6 & 33.8 & 8 & 2 & 2 \\
\hline & & 27 & 27.3 & 25.0 & 21.0 & 8 & 2 & 2 \\
\hline \multirow{3}{*}{$1 c$} & \multirow{3}{*}{ June 23- July 14} & 18 & 18.3 & 31.4 & 37.2 & 8 & 2 & 2 \\
\hline & & 23 & 23.4 & 30.6 & 26.5 & 8 & 2 & 2 \\
\hline & & 27 & 27.0 & 33.7 & 19.4 & 8 & 1 & 0 \\
\hline \multirow{2}{*}{$2 a$} & \multirow{2}{*}{ May 12-June 9} & 8 & 8.0 & 33.7 & 34.8 & 8 & 3 & 1 \\
\hline & & 13 & 12.8 & 32.3 & 28.6 & 8 & 3 & 1 \\
\hline \multirow{2}{*}{$2 b$} & \multirow{2}{*}{ June 9-July 7} & 8 & 9.1 & 20.3 & 35.5 & 8 & 3 & 3 \\
\hline & & 13 & 13.0 & 19.8 & 31.5 & 8 & 3 & 3 \\
\hline \multicolumn{2}{|c|}{ Total numbers of replicates } & & & & & & 29 & 22 \\
\hline
\end{tabular}

${ }^{1} \mathrm{BW}$ is the body weight of the fish

${ }^{2} W_{1}$ is the initial weight of the fish

${ }^{3} \mathrm{~W}_{2}$ is the final weight of the fish

Table 1: Summary of the experimental conditions for the study of effects of temperature on growth (SGR and TGC), feed intake (\% of BW $\left.{ }^{1}\right)$ and energy requirement (DEN, $\mathrm{kJ} \mathrm{DE} \cdot \mathrm{g}^{-1}$ ) of Eurasian perch (Perca fluviatilis). 
(DAN-EX 1344, $2 \mathrm{~mm}, 13 \%$ fat, $44 \%$ protein, 25\% carbohydrates, Dana feed, Horsens, Denmark,) in the feeders were weighed and the fish were tranquilized with $10 \mathrm{mg} \cdot \mathrm{L}^{-1}$ AQUACALM (MARINIL, Syndel Laboratories Ltd., Qualicum Beach, British Columbia) and their live weight and total length was recorded. After weighing, the fish were left alone in the experimental tanks for 24 hours to recover from the handling stress before feeding was initiated. For transfer of fish to the highest temperature, the temperature in the $27^{\circ} \mathrm{C}$ tanks was lowered to approximately $19^{\circ} \mathrm{C}$ when fish were introduced to the tanks and was then gradually increased to $27^{\circ} \mathrm{C}$ during the following 24 hours. New fish were used in each experimental round. The experimental data is summarized in Table 1.

After the temperature experiment, all fish (both fish used in the experiment and fish not used in the experiment) were divided into two tanks, one kept at approximately $17^{\circ} \mathrm{C}$ and one kept at approximately $12^{\circ} \mathrm{C}$ from July to January. This was done in order to increase the body size span among the fish of identical age in preparation for the body size study. In the end of January, the temperature was increased to $17^{\circ} \mathrm{C}$ in the previously cold water tank $\left(12^{\circ} \mathrm{C}\right)$, and was then maintained at $17^{\circ} \mathrm{C}$ for three and a half months until the body size experiment was started. This was done in order to reduce the risk of growth compensation occurring for the fish previously held in $12^{\circ} \mathrm{C}$ when the experiment was started. During this period (July-May), rearing conditions were similar to before the temperature experiment.

The body size study was performed in the same system with the same light, management and feeding regime settings as the temperature study. The temperature in each tank was recorded continuously by temperature loggers and were on average $( \pm S D) 21.1^{\circ} \mathrm{C}( \pm 0.6)$. The body size study was performed during May to June 2006 in two consecutive rounds of three weeks each, with fish at an age of approximately two years and between 20 and $110 \mathrm{~g}$. To avoid crowding and to maintain an even rearing density, number of fish in each group was reduced as body

\begin{tabular}{|c|c|c|c|c|c|c|}
\hline $\begin{array}{l}\text { Experimental } \\
\text { round }\end{array}$ & $\begin{array}{c}\text { Size } \\
\text { category }\end{array}$ & $\begin{array}{l}\text { Number of } \\
\text { individuals }\end{array}$ & $\begin{array}{c}\text { Average } \\
W_{1}\end{array}$ & $\begin{array}{c}\text { Average } \\
W_{2}\end{array}$ & $\mathrm{~K}_{1}$ & $\mathrm{~K}_{2}$ \\
\hline 1 & $20-50$ & 6 & 39.9 & 43.3 & 0.9 & 0.9 \\
\hline 1 & $20-50$ & 6 & 44.8 & 53.1 & 0.9 & 1.0 \\
\hline 1 & $20-50$ & 6 & 20.7 & 23.3 & 0.9 & 0.9 \\
\hline 1 & $20-50$ & 5 & 25.2 & 28.3 & 0.9 & 0.9 \\
\hline 1 & $50-80$ & 5 & 70.4 & 73.6 & 1.0 & 1.0 \\
\hline 1 & $50-80$ & 5 & 60.9 & 69.4 & 1.0 & 1.1 \\
\hline 1 & $50-80$ & 5 & 75.4 & 82.7 & 1.0 & 1.0 \\
\hline 1 & $80-110$ & 4 & 89.6 & 97.1 & 1.0 & 1.0 \\
\hline 2 & $20-50$ & 6 & 30.8 & 36.4 & 0.9 & 1.0 \\
\hline 2 & $20-50$ & 5 & 34.3 & 44.3 & 0.9 & 1.0 \\
\hline 2 & $20-50$ & 6 & 21.5 & 31.3 & 0.9 & 1.1 \\
\hline 2 & $20-50$ & 6 & 26.0 & 32.6 & 0.8 & 1.0 \\
\hline 2 & $50-80$ & 5 & 55.5 & 61.3 & 1.0 & 1.0 \\
\hline 2 & $50-80$ & 5 & 65.2 & 74.2 & 1.0 & 1.0 \\
\hline 2 & $80-110$ & 4 & 96.1 & 105.1 & 1.0 & 1.1 \\
\hline 2 & $80-110$ & 4 & 100.9 & 109.0 & 1.0 & 1.0 \\
\hline 2 & $80-110$ & 4 & 95.1 & 110.1 & 1.0 & 1.0 \\
\hline 2 & $80-110$ & 4 & 85.1 & 89.5 & 1.0 & 1.0 \\
\hline 2 & $80-110$ & 4 & 105.4 & 111.5 & 1.0 & 1.0 \\
\hline 2 & $80-110$ & 4 & 106.4 & 116.1 & 1.0 & 1.1 \\
\hline
\end{tabular}

Table 2: Summary of the experimental conditions for the study of effects of fish body size on growth (SGR and TGC), feed intake (\% of body weight) and energy requirement (DEN, $\mathrm{kJ} \mathrm{DE} \cdot \mathrm{g}^{-1}$ ) of Eurasian perch (Perca fluviatilis). $\mathrm{W}_{1}$ and $\mathrm{W}_{2}$ represents the initial and final weight of the fish and $\mathrm{K}_{1}$ and $\mathrm{K}_{2}$ represents the average condition factor at the start and end of the experiment. size of the fish increased. In size range 20 to $50 \mathrm{~g}$ six fish, in size range 50 to $80 \mathrm{~g}$ five fish, and in size range 80 to $110 \mathrm{~g}$ four fish were placed in each group. The entire size range (20-110 g) was represented in each experimental round by groups of fish with different average body size. Within each group, standard deviation (SD) of fish body live weight (g) was as most 2.8 , but on average $1.6 \mathrm{~g}$. Condition factors of the groups ranged between 0.84 and 1.04 but were in average $( \pm$ SD) $0.96( \pm 0.06)$ Average condition factors for each size category are displayed in Table 2. The same feed and weighing procedures for feed and fish was used as in the temperature experiment. New fish were used in each experimental round. The experimental data is summarized in Table 2.

\section{Calculations}

The SGR [13] and TGC [21] were used to calculate growth rate. SGR is expressed mathematically as:

$\mathrm{SGR}=\left(\ln \mathrm{W}_{2}-\ln \mathrm{W}_{1}\right) / \Delta \mathrm{t} \bullet 100$

TGC is expressed mathematically as:

$$
\mathrm{TGC}=\left(\mathrm{W}_{2}^{(1 / 3)}-\mathrm{W}_{1}^{(1 / 3)}\right) /(\mathrm{T} \bullet \Delta \mathrm{t}) \bullet 1000
$$

where $\mathrm{W}_{2}$ is the group average weight at time $\mathrm{t}(\mathrm{g}), \mathrm{W} 1$ is the group average initial weight $(\mathrm{g})$, $\mathrm{T}$ is the water temperature $\left({ }^{\circ} \mathrm{C}\right)$ and $\Delta \mathrm{t}$ is the duration of the experiment (number of days).

In both experiments, feed intake was calculated as weight of the feed delivered to each tank minus the number of collected pellets from the same tank multiplied by the average weight of one pellet. The feed intake was then expressed as $\%$ feed intake of average fish body weight per day and per fish.

The digestible energy need (DEN: $\left.\mathrm{kJ} \mathrm{DE}^{-1}{ }^{-1}\right)$ [12] describes the amount of digestible energy $(\mathrm{kJ})$ the fish needs to ingest to increase $1 \mathrm{~g}$ in wet weight. The DEN is calculated as:

$$
\mathrm{DEN}=(\mathrm{FI} \cdot \mathrm{DE}) /\left(\mathrm{W}_{2}-\mathrm{W}_{1}\right)
$$

where FI is the average feed intake per fish during the experimental period $(\mathrm{g})$ and DE is the digestible energy content of the feed $\left(\mathrm{kJ} \bullet \mathrm{g}^{-1}\right)$. Energy values of macronutrients $\left(23.7,36.3\right.$ and $17.2 \mathrm{~kJ} \bullet \mathrm{g}^{-1}$ for protein, fat and carbohydrates, respectively) were obtained from Brett \& Groves (1979) [3] and apparent digestibility coefficients (ADC) used were obtained from industry standards and were $0.87,0.90$ and 0.65 for protein, fat and carbohydrates, respectively (pers. comm. M. Jobling) From this, the following values were obtained and then used to calculate the digestible energy content of the feed: $20.6,32.7$ and $11.2 \mathrm{~kJ} \cdot \mathrm{g}^{-1}$ for protein, fat and carbohydrates, respectively.

Fulton's condition factor (K; [41]) of each group in the body size experiment was calculated as the average condition factor of all individuals in a group. The $\mathrm{K}$ is calculated as:

$$
\mathrm{K}=\mathrm{W}_{1} / \mathrm{L}^{\wedge} 3 \text { * } 100000
$$

where $L_{1}$ is the initial length of each fish $(\mathrm{mm})$.

\section{Statistics}

The statistical software used was SPSS 15.0 and Minitab 15.0 for Windows. For the temperature data, one group in temperature category $27^{\circ} \mathrm{C}$ died during the experiment and was thus excluded from the dataset. The resulting numbers of replicates for growth and feed intake data in $27^{\circ} \mathrm{C}$ were thus five. Moreover, despite a high feed intake, three of the groups in temperature category $27^{\circ} \mathrm{C}$ demonstrated negative growth rates. As accurate calculation of DEN from negative growth rates is not possible, energy requirement data for these replicates had to 
Citation: Strand Å, Magnhagen C, AlanäräA (2011) Growth and Energy Expenditures of Eurasian Perch Perca fluviatilis (Linnaeus) in Different Temperatures and of Different Body Sizes. J Aquac Res Development 2:114. doi:10.4172/2155-9546.1000114

from the dataset. This resulted in only two replicates for the DEN data in the $27^{\circ} \mathrm{C}$ temperature category. Due to low feed intake and the resulting negative growth, two replicates from $8^{\circ} \mathrm{C}$ and two from $13^{\circ} \mathrm{C}$ also had to be excluded from the DEN data (Table 1). Feed intake had to be square $\operatorname{root}\left(\mathrm{X}^{1 / 2}\right)$ transformed to fulfil homogeneity assumptions of univariate general linear models (GLM). The observed variations in growth (SGR and TGC) and feed intake were tested statistically using GLM (type III: unbalanced ANOVA), with temperature category $(8,13,18,23$ and $27^{\circ} \mathrm{C}$ ) as factor and tank number as nested factor. Tukey's test was used as post-hoc test. Despite transformation, DEN data did not fulfil homogeneity assumptions of univariate general linear models (GLM) and was therefore analyzed using robust ANOVA with Tamhane's T2 test as post-hoc test. Experimental round was not used as a covariate in the general temperature analysis due to the parallel experimental rounds of varying time length for low $\left(8-13^{\circ} \mathrm{C}\right.$, experimental rounds $2 \mathrm{a}$ and $\left.\mathrm{b}\right)$ and high $\left(18-27^{\circ} \mathrm{C}\right.$, experimental rounds $1 \mathrm{a}, \mathrm{b}$ and $\left.\mathrm{c}\right)$ temperatures. The effect of experimental round was evaluated separately for high and low temperatures, respectively. For high temperatures only two replicates were available for temperature category $27^{\circ} \mathrm{C}$ for the DEN data. As both existing replicates came from experimental round $1 \mathrm{~b}$, temperature category $27^{\circ} \mathrm{C}$ was excluded from experimental round analysis for the DEN data. The DEN data was analyzed using robust ANOVA with experimental round $\left(18\right.$ and $23^{\circ} \mathrm{C}: 1 \mathrm{a}, \mathrm{b}$ and c) as factor. Furthermore, in the low temperatures only one replicate per temperature category existed in experimental round 2 a thus no analysis was made regarding the effect of experimental round on DEN at low temperatures. The effect of experimental round on growth (SGR and TGC) and feed intake was evaluated using GLM (type III: unbalanced ANOVA) and with temperature category (high temperatures: 18,23 and $27^{\circ} \mathrm{C}$; low temperatures: 8 and $13^{\circ} \mathrm{C}$ ) and experimental round (high temperatures: 1a, b and c; low temperatures: $2 \mathrm{a}$ and b) as factors. Feed intake was transformed as in the previous analyses. Tank number was not used as a nested factor as it proved to be insignificant in the general analysis (Table 3). Tukey's test was used as post-hoc test.

For the body size data, four replicates (three from the largest size category and one from the middle size category) had to be excluded from the dataset due to technical problems with feeding, resulting in feed restriction of the fish during the experiment. The observed variations in growth (SGR and TGC), feed intake and energy requirement (DEN) were tested statistically using univariate general linear models (GLM) with experimental round (1 and 2) as factor and average body weight (Ln transformed) as covariate. Condition factor (K) of the fish was also initially used as a covariate in the GLM analysis, but as it turned out to be insignificant for all variables it was excluded from further analysis. The effect of body size on condition factor $(\mathrm{K})$ of the fish was, however, evaluated using linear regression analysis with average weight (Ln transformed) as factor. The effect of body weight on growth (SGR and TGC), feed intake and energy requirement (DEN) was then evaluated using linear models $(\mathrm{Y}=\mathrm{A}+\mathrm{B} \cdot \mathrm{X})$ with average body weight ( $\mathrm{Ln}$ transformed) as X.

\section{Results}

\section{Temperature data}

Growth rate (SGR and TGC) and feed intake (Table 3) and DEN (robust ANOVA, $\mathrm{F}_{4,17}=6.77, \mathrm{P}=0.002$ ) were significantly affected by temperature. Tank number did not affect the results significantly (Table 3). Growth (SGR and TGC) increased with temperature from 8 to $23^{\circ} \mathrm{C}$, and was then reduced at $27^{\circ} \mathrm{C}$. However, growth was only significantly higher in 18 and $23^{\circ} \mathrm{C}$ than in 8,13 and $27^{\circ} \mathrm{C}$, but did not differ between 18 and 23 , or between 8,13 and $27^{\circ} \mathrm{C}$, respectively (Tukey post hoc test $\mathrm{P}<0.05$ ) (Figure 1). Feed intake followed a similar pattern but differences were significant between all temperature categories except for between 18 and $27^{\circ} \mathrm{C}$ (Tukey post hoc test $\mathrm{P}<0.05$ ) (Figure 1). DEN at $27^{\circ} \mathrm{C}$ was higher compared to all other temperature categories but did not differ between temperature categories $8-23^{\circ} \mathrm{C}$ (Tamhane's T2 post hoc test, Figure 1).

Moreover, at high temperatures $\left(18-27^{\circ} \mathrm{C}\right)$, growth (SGR and TGC), feed intake (Table 3 ) and energy requirement (DEN) (robust ANOVA, $\mathrm{F}_{2,9}=23.60, \mathrm{P}<0.001$ ) were significantly affected by experimental round. Growth (TGC; Tukey post-hoc test, $\mathrm{P}=0.002$ but not SGR) and feed intake (Tukey post-hoc test, $\mathrm{P}=0.038$ ) were significantly higher, and energy requirement (DEN) (Tamhane's $\mathrm{T} 2$ post hoc test, $\mathrm{P}=0.025$ ) was significantly lower, in experimental round $1 \mathrm{c}$ compared to in round 1a. Furthermore, growth (SGR; Tukey post-hoc test, $\mathrm{P}=0.021$, TGC Tukey post-hoc test, $\mathrm{P}=0.004$ ) was higher and energy requirement (DEN) (Tamhane's $\mathrm{T} 2$ post hoc test, $\mathrm{P}=0.018$ ) was lower in round $1 \mathrm{~b}$

\begin{tabular}{|c|c|c|c|c|c|c|c|c|}
\hline & & & \multicolumn{2}{|c|}{ SGR } & \multicolumn{2}{|c|}{ TGC } & \multicolumn{2}{|c|}{$\begin{array}{l}\text { Feed intake } \\
\left(\% \text { of } \mathrm{BW}^{1}\right)\end{array}$} \\
\hline & & $d f$ & $\mathrm{~F}$ & $\mathrm{P}$ & $\mathrm{F}$ & $\mathrm{P}$ & $\mathrm{F}$ & $P$ \\
\hline \multirow{2}{*}{ All temperature categories } & $\begin{array}{l}\text { Temperature } \\
\text { category }\end{array}$ & 4,17 & 96.98 & $<0.001$ & 35.57 & 0.001 & 102.93 & $<0.001$ \\
\hline & Tank number & 7,17 & 0.23 & 0.972 & 0.37 & 0.906 & 0.80 & 0.601 \\
\hline \multirow{3}{*}{$\begin{array}{l}\text { High temperature catego- } \\
\text { ries }\end{array}$} & $\begin{array}{l}\text { Temperature } \\
\text { category }\end{array}$ & 2,8 & 14.82 & 0.002 & 73.86 & $<0.001$ & 14.65 & 0.002 \\
\hline & Round & 2,8 & 5.92 & 0.026 & 11.43 & 0.005 & 4.59 & 0.047 \\
\hline & $\begin{array}{c}\text { Temperature } \\
\text { category }{ }^{*} \text { Round }\end{array}$ & 4,8 & 0.82 & 0.547 & 1.61 & 0.262 & 0.641 & 0.648 \\
\hline \multirow{3}{*}{ Low temperature categories } & $\begin{array}{l}\text { Temperature } \\
\text { category }\end{array}$ & 1,8 & 1.84 & 0.212 & 0.52 & 0.492 & 13.09 & 0.007 \\
\hline & Round & 1,8 & 18.06 & 0.003 & 15.80 & 0.004 & 1.46 & 0.262 \\
\hline & $\begin{array}{l}\text { Temperature } \\
\text { category }{ }^{\star} \text { Round }\end{array}$ & 1,8 & 0.26 & 0.623 & 1.85 & 0.211 & $<0.00$ & 1.000 \\
\hline
\end{tabular}

${ }^{1} \mathrm{BW}$ is the body weight of the fish

Table 3: General linear model analyses (GLM, type III, unbalanced ANOVA) of the effect of temperature category (low $=8$ and $13^{\circ} \mathrm{C}$, high $=18,23$ and $27^{\circ} \mathrm{C}$ ) and experimental round ( $1 \mathrm{a}, \mathrm{b}$ and $\mathrm{c}$ for high temperatures and $2 \mathrm{a}$ and $\mathrm{b}$ for low temperatures) on growth (SGR and TGC) and feed intake (\% of BW $\left.{ }^{1}\right)$ of Eurasian perch (Perca fluviatilis) from the temperature study. For the general analysis (only temperature categories), tank number was used as a nested factor. In the table are degrees of freedom ( $d f$ ) and $\mathrm{F}$ - and $\mathrm{P}$ - values for growth rates (SGR and TGC), feed intake and energy requirements (DEN) demonstrated. 
Citation: Strand Å, Magnhagen C, Alanärä A (2011) Growth and Energy Expenditures of Eurasian Perch Perca fluviatilis (Linnaeus) in Different Temperatures and of Different Body Sizes. J Aquac Res Development 2:114. doi:10.4172/2155-9546.1000114

compared to in round 1a. In the low temperatures $\left(8-13^{\circ} \mathrm{C}\right)$, growth was also significantly higher (SGR and TGC) in round $2 \mathrm{~b}$ than in round $2 \mathrm{a}$ while feed intake was unaffected by experimental round (Table 3 ).

\section{Body size data}

Growth (SGR and TGC), feed intake and energy requirement (DEN) were significantly affected by average body weight of the fish (Table 4). Growth (SGR and TGC) was also affected significantly by experimental round (Table 4), and increased from experimental round one to

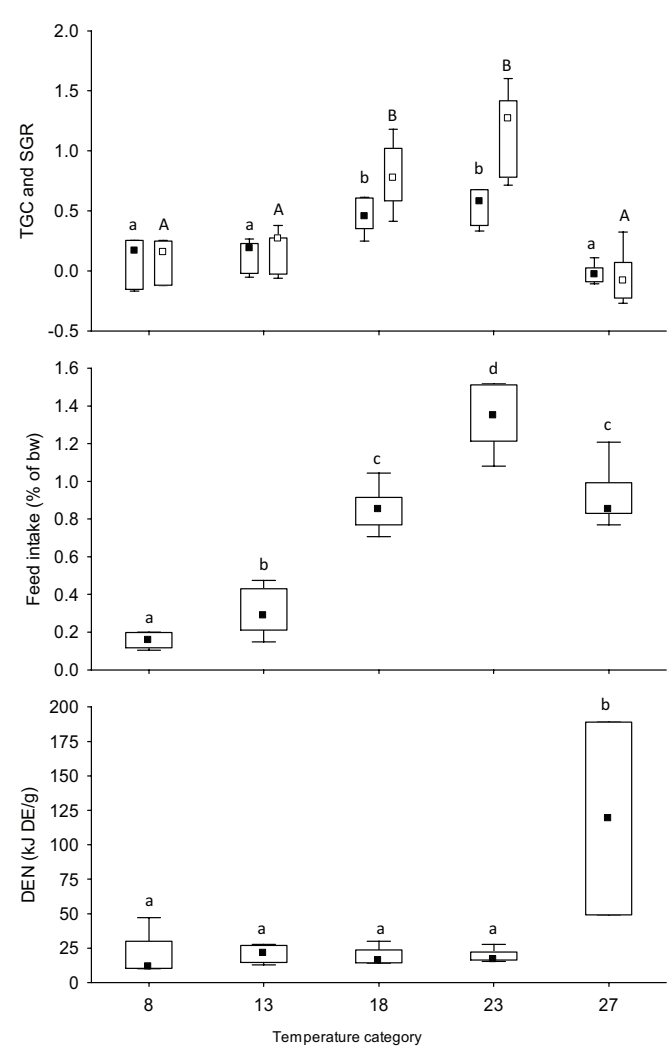

Figure 1: Box-plots of growth rates (SGR and TGC), feed intake (\% of BW) and energy requirement (DEN, $\left.\mathrm{kJ} \mathrm{DE} \bullet \mathrm{g}^{-1}\right)$ of Eurasian perch (Perca fluviatilis) in different temperature categories $\left(8,13,18,23\right.$ and $\left.27^{\circ} \mathrm{C}\right)$. Square symbols within boxes represent the median of the sample (white square symbols for SGR and black square symbols for TGC), boxes represent quartiles and the whiskers show non-outlier range. Identical lower and upper case letters indicates no significant differences $(P>0.005)$ between temperature categories. For growth rates (SGR and TGC) and feed intake, number of replicates in temperature categories $8-23^{\circ} \mathrm{C}$ were six and in category $27^{\circ} \mathrm{C}$ five. For the energy requirement (DEN) data, numbers of replicates were four in temperature category 8 and $13^{\circ} \mathrm{C}$, and six in categories 18 and $23^{\circ} \mathrm{C}$

\begin{tabular}{|l|l|l|l|l|}
\hline & & GLM & & \\
\hline & $\mathrm{N}$ & $\mathrm{P}\left(\mathrm{BW}^{1}\right)$ & $\mathrm{P}$ (Experimental round) & Model \\
\hline SGR & 20 & 0.001 & 0.041 & SGR $=2.49-0.45 \cdot \operatorname{InW}$ \\
\hline TGC & 20 & 0.015 & 0.040 & $\mathrm{TGC}=0.97-0.15 \cdot \ln W$ \\
\hline Feed intake & 20 & 0.005 & 0.136 & $\mathrm{FI}=2.14-0.32 \cdot \ln W$ \\
\hline DEN & 20 & 0.019 & 0.079 & DEN=1.70+5.41 $\ln W$ \\
\hline
\end{tabular}

Table 4: General linear model analyses (GLM, type III, unbalanced ANOVA) and regression analysis of the effect of average body weight (BW) and experimental round (1 and 2) on growth (SGR and TGC), feed intake (\% of BW) and energy requirement (DEN, $\mathrm{kJ} \mathrm{DE} \cdot \mathrm{g}^{-1}$ ) of Eurasian perch (Perca fluviatilis) from the body size study. In the table is number of replicates, $P$ - values and the resulting linear models for growth rates, feed intake and energy requirements demonstrated. W represents the weight of the fish.
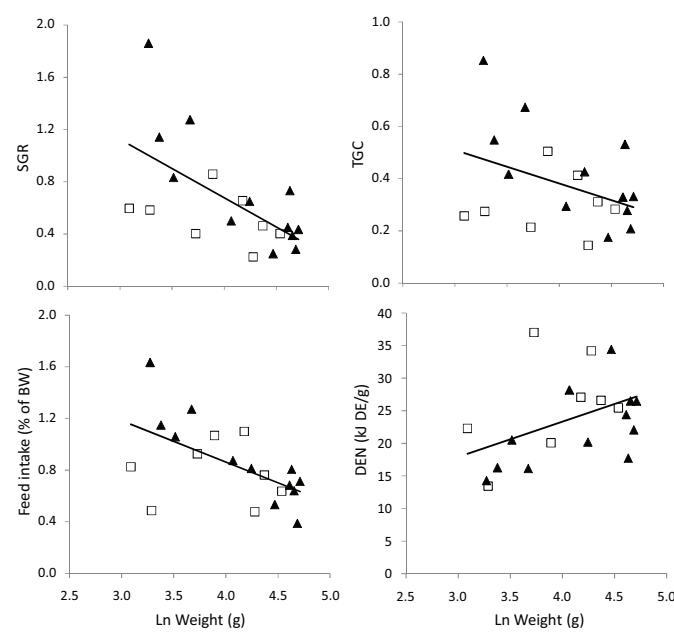

Figure 2: Linear models of growth (SGR and TGC), feed intake (\% of BW) and energy requirement (DEN; $\mathrm{kJ} \mathrm{DE} \cdot \mathrm{g}^{-1}$ ) of Eurasian perch (Perca fluviatilis) of different size. Average weight of the fish (g) was In transformed in the analysis. White squares $(\square)$ represent data from experimental round one and grey triangles $(\triangle)$ represent data from experimental round two.

round two. Neither feed intake nor energy requirement were affected by experimental round. Development of the linear models revealed a decreasing growth rate (SGR and TGC) and feed intake and an increasing energy requirement (DEN) of fish with increasing body size (Figure 2). Furthermore, the condition factor $(\mathrm{K})$ of the fish was significantly increased with increasing size of fish (linear regression analysis, $\left.\mathrm{F}_{1,18}=35,51, \mathrm{P}<0.001\right)$.

\section{Discussion}

Our prediction that TGC of perch is unaffected by temperature and body size was not fulfilled. In this study, TGC of perch was affected by temperature in a similar way as SGR, and thus follow the classical bellshaped curve of increasing growth rate with increasing temperature to an intermediate temperature, after which the growth rate declines. The effect of reduced TGC for perch at low temperatures is in contrast with data on rainbow trout Oncorhynchus mykiss (Walbaum) for which TGC has been found to be unaffected by temperature within a range of temperatures below the optimal for growth [24-26]. There are indications that cold water adapted species may have evolved a compensatory response to the low temperatures of their environment, thereby maintaining a metabolic rate at low temperatures above the expected $[3,42]$. Thus, if feed is not restricted at low temperatures, cold water adapted species may have a higher growth potential than warm water adapted species due to the higher metabolic rate.

Furthermore, TGC has been reported to be unaffected by body size of fish [22-24]. Even though the size interval used in this study was quite limited, a clear negative relationship was found between body size of the fish and TGC. This is similar to the response of SGR with varying body size of fish $[5,22]$. The condition factor of the fish was found to increase significantly with increasing body size of the fish. Allometric growth with increasing condition factors with increasing body size is common in fish $[43,44]$. One assumption for use of the TGC coefficient is that the relationship between weight and length of the fish is constant, i.e. isometric growth occurs, thus TGC should only be used when the condition factor remains stable [28]. This may explain the size dependence of TGC found in this study. The temperature and body size dependence of TGC for perch causes the same problems in 
data collection for growth model construction as does SGR. For perch, the TGC thus lose its advantage as a simple coefficient for practical use in aquaculture.

The digestible energy need of perch increased exponentially at temperatures above $23^{\circ} \mathrm{C}$. Below $23^{\circ} \mathrm{C}$, the relationship between temperature and DEN are in accordance with the data presented by Bailey and Alanärä [32] on percid fish species, i.e. no clear relationship. A positive relationship between temperature and energy expenditures should exist $[5,30,31]$, but the effect of metabolic costs might be too small to detect without excessive replication. At $27^{\circ} \mathrm{C}$, two groups of fish out of the five demonstrated very high DEN values and in the remaining three, energy expenditures were too high to allow positive net growth to occur. This supports the theory of an exponential increase in energy expenditures when temperature exceeds the normal range of growing temperatures $[3,5,6,32]$. Thus, $27^{\circ} \mathrm{C}$ seem to be close to the tolerance temperature for perch of this strain.

Our prediction that DEN of perch is affected by body size was, however, fulfilled. DEN of perch was found to increase significantly with increasing body size, which is in contrast with the data on percid fish presented by Bailey and Alanärä [32]. However, the percid data presented in that article is quite scattered and mainly focuses on sea bass Dicentrarchus labrax (Linnaeus) and sea bream Sparus aurata (Linnaeus). In accordance with the theoretical background provided earlier, perch seems to follow the same pattern of increased energy expenditures with increasing body size of fish as demonstrated for other species such as cod Gadus morhua (Linnaeus) [45,46], several different salmonid species and flatfish [32].

One question that must be addressed in connection with the method used to achieve different sized fish of the same age by growing them in different temperatures before the body size experiment is whether this treatment caused a compensatory growth of the fish kept in the low temperature. Most existing information on compensatory growth is connected to feed restriction of the fish, and knowledge about effects and duration of compensatory growth is quite scattered [47]. In this study, the fish kept in low temperature between the temperature and the body size experiments were never feed restricted. Growth compensation may, however, have occurred after the temperature was increased due to the previous temperature restriction. In earlier studies of compensatory growth after temperature manipulation in salmonid fish, growth compensation was complete in four [48], ten [49] and approximately 20 weeks [50]. In our study, the fish had 14 weeks to recover from the temperature restriction before the body size experiment started. This should have allowed for growth compensation to occur and to subside again. Growth rates of small fish during experimental round one was in fact lower than that of small fish in round two, indicating that growth compensation due to the restricted temperature between the experiments was not occurring at that stage. Furthermore, the condition factors of fish in experimental round one did not increase significantly from the start to the end of the round which also indicates that no compensatory growth occurred at that point.

In the present study, small groups of fish were used (four to eight individuals per group depending on study and treatment). Dominance hierarchies in small groups of fishes are often established through aggressive behaviour of dominant individuals towards subordinate individuals [51,52]. Aggressive behaviour in small groups of perch has been observed in a few cases [53] but often no aggression can be observed [54]. Whether aggressive behaviour leads to dominance hierarchies in perch is unclear.
When dominance hierarchies are established, feed intake of subordinate individuals is reduced and energy expenditures of both dominant and subordinate fish are increased due to aggressive acts and stress responses [52]. In a study performed by Strand et al. [38], fish held in small groups had significantly lower feed intake, but also higher feed efficiency (lower energy expenditures) than solitary individuals. This indicates that dominance hierarchies were not the reason for the lower feed intake of fish in small groups in the study performed by Strand et al. [38]. Furthermore, perch is a schooling species, finding security in numbers. Thus the results obtained by Strand et al. [38] and the social preferences of the species make the occurrence of dominance hierarchies in the groups used in this study unlikely. Groups of fish may also compete for limited resources. However, during the study, the fish were constantly over-fed, thus competition for feed should not have occurred.

Rearing densities may also affect performance of cultured fish. In this study, rearing densities were deliberately maintained low $(2-5 \mathrm{~kg}$. $\mathrm{m}^{-3}$ in the temperature study and $3-8 \mathrm{~kg} \cdot \mathrm{m}^{-3}$ in the size study) to avoid crowding and water quality deterioration. In the size experiment the size classes and the number of fish included in the groups in each size class were designed to produce an even rearing density of fish in the experimental tanks and to reduce the risk of crowding when large fish were used. Therefore the number of fish per tank had to be reduced as size of the fish increased. Furthermore, in the study performed by Strand et al. [38], fish held in groups of 4 and 12 individuals (2-6 kg . $\mathrm{m}^{-3}$ ) demonstrated high growth rates, thus the rearing densities used in this study was sufficient to provide adequate conditions for good growth of the fish.

In the temperature experiment, growth rates and feed intake increased, and energy requirement decreased, from the first experimental round to the final round. The same trend could be noted for growth of perch in the body size experiment. As both experiments were performed during late spring and early summer, the increase in feed intake and growth with time may be the result of a release of a winter suppression of appetite and growth. Similar seasonal increases in feed intake and growth at constant temperatures have previously been noted for perch $[39,40]$. Nevertheless, the main results regarding the effect of temperature and body size on the growth, feed intake, and energy requirements of juvenile perch are not affected by the differences between the rounds.

In conclusion, the prediction that TGC of perch would be unaffected by temperature and body size was not fulfilled. TGC proved to be significantly affected both by temperature and body size of the fish in a similar manner as is SGR. The advantages with TGC for growth model construction thus seem to be less apparent than earlier believed. In contrast, DEN was predicted to be affected by both temperature and body size of the fish, but was only found to be significantly affected by body size. DEN was not affected by temperature at or below optimal temperatures for growth, but as temperature increased further, energy expenditures seemed to increase exponentially.

\section{Acknowledgment}

We thank Eastern Norrbotten Research Station for providing financial support for this project and Carl Tryggers Foundation for financial support to the experimental setup. We also thank Andreas Åkerström for valuable comments on the manuscript.

\section{References}

1. MacEwan G (1945) The feeding of farm animals. The Hunter-Rose Co. Limited Toronto. 
Citation: Strand Å, Magnhagen C, AlanäräA (2011) Growth and Energy Expenditures of Eurasian Perch Perca fluviatilis (Linnaeus) in Different Temperatures and of Different Body Sizes. J Aquac Res Development 2:114. doi:10.4172/2155-9546.1000114

2. Bull S, Carroll WE (1946) Principles of feeding farm animals. The Interstate Printers and Publishers, Danville, Illinois.

3. Brett JR, Groves TDD (1979) Physiological energetics. In: Fish physiology, vol. VIII. Hoar WS, Randall DJ, Brett JR (Eds.) Academic Press Inc. Ltd., London.

4. Brafield AE (1985) Laboratory studies of energy budgets. In: Fish energetics: new perspectives. P. Tytler P, Calow P (Eds.) Croom Helm Australia Sydney.

5. Jobling M (1994) Fish bioenergetics. Chapman \& Hall, London.

6. De Silva SS, Anderson TA (1995) Energetics. In: Fish nutrition in aquaculture. De Silva SS, Anderson TA (Eds.) St Edmundsbury Press, Suffolk.

7. Jobling $M$ (1983) A short review and critique of methodology used in fish growth and nutrition studies. J Fish Biol 23: 685-703.

8. Talbot C (1985) Laboratory methods in fish feeding and nutritional studies. In: Fish energetics: new perspectives. P. Tytler P, Calow P (Eds.) Croom Helm Australia Pty Ltd, Sydney.

9. Cui Y, Wootton RJ (1989) Bioenergetics of growth of a cyprinid, Phoxinus phoxinm (L.): development and testing of a growth model. J Fish Biol 34: 47-64.

10. Ney JJ (1993) Bioenergetics modeling today: growing pains on the cutting edge. Trans Am Fish Soc 122: 736-748.

11. Cui Y, Xie S (2000) Modeling Growth in Fish. In: Feeding systems and feed evaluation models. Theodorou MK, France J (Eds.) CAB International, Wallingford.

12. Alanärä A, Kadri S, Paspatis $M$ (2001) Feeding management. In: Food intake in fish. Houlihan D, Jobling M, Boujard T (Eds.) Blackwell Science, Oxford.

13. Ricker WE (1979) Growth rates and models. In: Fish physiology, vol. VIII. Hoar WS, Randall DJ, Brett JR (Eds.) Academic Press Inc. Ltd., London.

14. Burel C, Person-Le Ruyet J, Gaumet F, Le Roux A, Sévère A, et al. (1996) Effects of temperature on growth and metabolism in juvenile turbot. J Fish Biol 49: 678-692.

15. Tidwell JH, Coyle SD, Evans J, Weibel C, McKinnley J, et al. (1999) Effect of temperature on growth, survival, and biochemical composition of yellow perch Perca flavescens. J World Aqua Soc 30: 324-330.

16. Björnsson B, Steinarsson A (2002) The food-unlimited growth rate of Atlantic cod (Gadus morhua). Can J Fish Aquat Sci 59: 494-502.

17. Person-Le Ruyet J, Mahé K, Le Bayon N, Le Delliou H (2004) Effects of temperature on growth and metabolism in a Mediterranean population of European sea bass, Dicentrarchus labrax. Aquaculture 237: 269-280.

18. Jobling M (1983) Growth studies with fish-overcoming the problem of size variation. J Fish Biol 22: 153-157.

19. Iwama GK, Pickering AD, Sumpter JP, Schreck CB (1997) Fish stress and health in aquaculture. Cambridge University Press, Cambridge.

20. Bureau DP, Azevedo PA, Tapia-Salazar M, Cuzon G (2000) Pattern and cost of growth and nutrient deposition in fish and shrimp: Potential implications and applications. In: Avances en Nutrición Acuícola V. Cruz-Suárez LE, Ricque-Marie D, Tapia-Salazar M, Olvera-Novoa MA, Civera-Cerecedo R (Eds.) Fish nutrition research laboratory, Mérida, Yucatán.

21. Iwama GK, Tautz AF (1981) A Simple Growth Model for Salmonids in Hatcheries. Canadian J Fish Aquat Sci 38: 649-656.

22. Kaushik SJ (1998) Nutritional bioenergetics and estimation of waste production in non-salmonids. Aquat Living resour 11: 211-217.

23. Kaushik SJ (1995) Nutrient requirements, supply and utilization in the context of carp culture. Aquaculture 129: 225-241.

24. Cho CY, Bureau DP (1998) Development of bioenergetic models and the Fish-PrFEQ software to estimate production, feeding ration and waste output in aquaculture. Aquat Living Resour 11: 199-210.

25. Azevedo PA, Cho CY, Leeson S, Bureau DP (1998) Effects of feeding level and water temperature on growth, nutrient and energy utilization and waste outputs of rainbow trout (Oncorhynchus mykiss). Aquat Living Resour 11: 227-238.

26. Bailey J, Alanärä A (2006) Effect of portion size on growth of rainbow trout, Oncorhynchus mykiss (Walbaum), reared at different temperatures. Aquaculture 253: 728-730

27. Cho CY (1992) Feeding systems for rainbow trout and other salmonids with reference to current estimates of energy and protein requirements. Aquaculture 100: 107-123

28. Jobling M (2003) The thermal growth coefficient (TGC) model of fish growth: a cautionary note. Aquac Res 34: 581-584.

29. Rónyai A, Csengeri I (2008) Effect of feeding regime and temperature on on-growing results of pikeperch (Sander lucioperca L.). Aquac Res 39: 820827.

30. Brett JR (1979) Environmental factors and growth. In: Fish physiology vol. VIII Hoar WS, Randall DJ, Brett JR (Eds.) Academic Press Inc. Ltd., London.

31. Brett JR (1995) Energetics. In: Physiological ecology of pacific salmon. Groot C, Margolis L, Clarke WC (Eds.) UBC Press, Vancouver.

32. Bailey J, Alanärä A (2006) Digestible energy need (DEN) of selected farmed fish species. Aquaculture 251: 438-455.

33. Strand $\AA$, Magnhagen $C$, Alanärä A (2007) Effects of repeated disturbances on feed intake, growth rates and energy expenditures of juvenile perch, Perca fluviatilis. Aquaculture 265: 163-168.

34. Mélard C, Kestemont P, Grignard JC (1996) Intensive culture of juvenile and adult Eurasian perch ( $P$. fluviatilis): effect of major biotic and abiotic factors on growth. J Appl ichtyol 12: 175-180.

35. Kestemont P, Jourdan S, Houbart M, Mélard C, Paspatis M, et al. (2003) Size heterogeneity, cannibalism and competition in cultured predatory fish larvae: biotic and abiotic influences. Aquaculture 227: 333-356

36. Hokanson KEF (1977) Temperature requirements of some percids and adaptations to the seasonal temperature cycle. Journal of the Fisheries Research Board of Canada 34: 1524-1550.

37. Kestemont P, Mélard C (2000) Aquaculture- In: Percid fishes, systematics, ecology and exploitation. Craig JF (Ed.) MPG Books Ltd Bodmin Cornwall.

38. Strand A, Alanärä A, Magnhagen C (2007) Effect of group size on feed intake, growth and feed efficiency of juvenile perch. J Fish Biol 71: 615-619.

39. Karås $P$ (1990) Seasonal changes in growth and standard metabolic rate of juvenile perch, Perca fluviatilis L. J Fish Biol 37: 913-920

40. Staffan F, Magnhagen C, Alanärä A (2005) Individual feeding success of juvenile perch is consistent over time in aquaria and under farming conditions. J Fish Biol 66: 798-809.

41. Fulton TW (1904) The rate of growth of fishes. Fisheries Board of Scotland Annual report 22: 141-241.

42. MacDonald JA, Montgomery JC, Wells RMG (1988) Comparative physiology of Antarctic fishes. Adv mar biol 24: 321-388

43. Andersson RO, Gutreuter SJ (1983) Length, weight, and associated structural indices. In: Fisheries techniques Mielsen LA, Johnson DL (Eds.) Southern Printing company Inc, Blacksburg, Virginia.

44. Cone RS (1989) The need to reconsider the use of condition indices in fishery science. Trans Am Fish Soc 118: 510-514.

45. Jobling $M$ (1988) A review of the physiological and nutritional energetics of cod, gadus morhua L., with particular reference to growth under farmed conditions. Aquaculture 70: 1-19.

46. Björnsson B, Steinarsson A, Oddgeirsson M (2001) Optimal temperature for growth and feed conversion of immature cod (Gadus morhua L.). Journal of Marine Science 58: 29-38.

47. Ali M, Nicieza A, Wootton RJ (2003) Compensatory growth in fishes: a response to growth depression. Fish and Fisheries 4: 147-190.

48. Nicieza AG, Metcalfe NB (1997) Growth compensation in juvenile atlantic salmon: responses to depressed temperature and food availability. Ecology 78: 2385-2400.

49. Mortensen A, Damsgård B (1993) Compensatory growth and weight segregation following light and temperature manipulation of juvenile Atlantic salmon (Salmo salar L.) and Arctic charr (Salvelinus alpinus L.). Aquaculture 114: $261-272$. 
Citation: Strand Å, Magnhagen C, AlanäräA(2011) Growth and Energy Expenditures of Eurasian Perch Perca fluviatilis (Linnaeus) in Different Temperatures and of Different Body Sizes. J Aquac Res Development 2:114. doi:10.4172/2155-9546.1000114

Page 8 of 8

50. MacLean A, Metcalfe NB (2001) Social status, access to food, and compensatory growth in juvenile Atlantic salmon. J Fish Biol 58: 1331-1346.

51. Brännäs E, Alanärä A, Magnhagen C (2001) The social behaviour of fish. In: Social behaviour in farm animals. Keeling LJ, Gonyou HW (Eds.) New York, CABI publishing.

52. Gilmour KM, DiBattista JD, Thomas JB (2005) Physiological causes and consequences of social status in salmonid fish. Integr Comp Biol 45: 263-273.

53. Westerberg M, Staffan F, Magnhagen C (2004) Influence of predation risk on individual competitive ability and growth in Eurasian perch, Perca fluviatilis. Anim Behav 67: 273-279.

54. Staffan F, Magnhagen C, Alanärä A (2002) Variation in food intake within groups of juvenile perch. J Fish Biol 60: 771-774. 